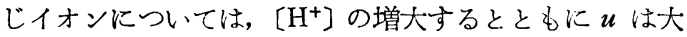
きくなり $\mathrm{pH}$ が減少するとともに陰極に间って移動度が 大になる傾向が説明される。

総括

1) $\mathrm{HPO}_{3},\left(\mathrm{HPO}_{3}\right)_{3},\left(\mathrm{HPO}_{3}\right)_{6}$ に $\mathrm{NaOH}$ あるいは $\mathrm{HCl}$ を添加して $\mathrm{pH}$ を種々に变化せしめた溶液を極液と し, 同液で飽和された濾紙上で, $\mathrm{Ni}^{2+}, \mathrm{Co}^{2+}, \mathrm{Zn}^{2+}, \mathrm{Cu}^{2+}$, $\mathrm{Cd}^{2+}$ の試験用イオンについて極液の $\mathrm{pH}$ とイオンの濾 紙上の移動度との関係を調べた. $\mathrm{HPO}_{3}$ の場合には $\mathrm{pH} 2$ 以上では錯塩を形成して陽極側に移動し，その移動度は $\mathrm{pH}$ によって余り変化しない. $\mathrm{pH} 1.7$ 以下では各イオン は陰極側に向って次第に大きく動き，移動度が相互に異 ってくる. $\left(\mathrm{HPO}_{3}\right)_{3}$ では $\mathrm{pH} 5.6$ 以上では錯塩を形成し, 陽極側に移動し，pH 5.6 でもかなりイオン相互の移動 度が異っている， pH 1.25 以下では錯塩をつくらなくな り, 陰極側に向って大きく移動し，イオン相互の移動度 の差は更に大きくなる. $\left(\mathrm{HPO}_{3}\right)_{6}$ では極液の $\mathrm{pH}$ を下 ザるとともに，イオンの移動度は減少するが， $\mathrm{pH} \mathrm{0.6}$ そ至ってもなお錯塩は安定て陽極へ移動し, その移動度 が相互に異る点がないため分離目的には適さない。

2）分離可能性のある酸性領域において各種混合イオ ンの分離をおこなった. すなわち $\mathrm{HPO}_{3}$ については $\mathrm{pH}$ 1.5 に扣いて $\mathrm{Fe}^{3+}, \mathrm{Al}^{3+} ; \mathrm{Zn}^{2+}, \mathrm{Co}^{2+}, \mathrm{Ni}^{2+} ; \mathrm{Ca}^{2+}, \mathrm{Ba}^{2+}$ $\left(\mathrm{Sr}^{2+}\right) ; \mathrm{Ni}^{2+}, \mathrm{Cu}^{2+}, \mathrm{Fe}^{3+} ; \mathrm{Ni}^{2+}, \mathrm{Zn}^{2+}, \mathrm{Al}^{3+}$ および $\mathrm{Ni}^{2+}$, $\mathrm{Cd}^{2+}, \mathrm{Fe}^{3+}$ の分離を $\left(\mathrm{HPO}_{3}\right)_{3}$ については, $\mathrm{pH} 1.6$ に拉 いて $\mathrm{Zn}^{2+}, \mathrm{Co}^{2+}, \mathrm{Ni}^{2+} ; \mathrm{Fe}^{3+}, \mathrm{Al}^{3+}$ および $\mathrm{Bi}^{3+}, \mathrm{Pb}^{2+}$, $\mathrm{Cu}^{2+}, \mathrm{Cd}^{2+} \mathrm{pH}$ 1. $7_{5}$ に打いて $\mathrm{Ca}^{2+}, \mathrm{Sr}^{2+} ; \mathrm{Cd}^{2+}, \mathrm{Al}^{3+}$; $\mathrm{Fe}^{3+} ; \mathrm{Ni}^{2+}, \mathrm{Cu}^{2+}, \mathrm{Sb}^{3+}, \mathrm{Fe}^{3+} ; \mathrm{Ba}^{2+}, \mathrm{Zn}^{2+}, \mathrm{Pb}^{2+}, \mathrm{Fe}^{3+}$ お。
よび $\mathrm{Ba}^{2+}, \mathrm{Co}^{2+}, \mathrm{Al}^{3+}, \mathrm{Fe}^{3+}$ の諸分離例をしめした。

3）ボリ燐酸, メ夕燐酸使用によるイオンの分離機構 については酸性における各種の燐酸 $\mathrm{H}_{2} \mathrm{R}$ と任意の試料 イオン $\mathrm{M}^{2+}$ が錯塩 $\mathrm{MR}$ を形成する反応

$$
\mathrm{H}_{2} \mathrm{R}+\mathrm{M}^{2+} \rightleftarrows \mathrm{MR}+2 \mathrm{H}^{+}
$$

の平衡恒数を $K$ とすると

イオンの移動度 $u$ は

$$
u=U \times \frac{\left[\mathrm{H}^{+}\right]^{2}}{K\left[\mathrm{H}_{2} \mathrm{R}\right]+\left[\mathrm{H}_{+}\right]^{2}}
$$

( $U$ は全部 $\mathrm{M}^{2+}$ に解離せるときのイオンの移動度) で現わされるから，平衡恒数Kの異るイオンは相互に分 離されると考兄られ，同じイオンについては $\left[\mathrm{H}^{+}\right]$の增 大とともに，にの移動度が陰極側に大さくなることが説 明される。

本研究に御指導, 御助言を戴いた元東京工業大学教授, 現立教大学教授兼在仏日本館及長植村愐先生, 東京工業 大学教授岩崎岩次先生，金沢大学柴田村治氏に厚く感謝 致します。な敃実験を熱心に援助された園山礼子氏なら びに，下記交献 2)に関して詳細なる書簡を戴いた木曾 義之氏に深謝致します。（昭和29年 9 月18日，日本化学 会常会講演)

$$
\text { 交献 }
$$

1) 牧: 分析化学, 4, 302 (1955).

2）木曾: 昭 29.4 日本化学会講演, 燐酸塩のペーパ 一クロマトグラフによる分離, 詳細は同氏書簡に よる。

3) 牧: 分析化学, 4, 21 (1955).

\title{
微量嗍素の光電比色定量法
}

\author{
川口浩
}

\section{The Colorimetric Determination of Trace Quantities of Boron.}

\author{
HiROSHI KawAGUCHI
}

(Earth Science Institute, Faculty of Science, Nagoya University)

The spectroscopic and volumetric methods are widely employed for the analyses of trace quantities of boron. Of the volumetric analyses, Chapin's method and its improved ones are most useful. But it should not be disregarded the effect of carbonic acid in these methods. As the removal of the effect of carbonic acid is considerably difficult, these methods are suitable only for the macro crder of boron and not for trace quantities of boron. Therefore, the author tried the colorimetric method for the trace quantities of boron in ground water, plants, rocks and metals etc. and obtained satisfactory results by use of the following procedure: Boron in sample is distilled with methyl alcohol in the quartz apparatus and the resultant ester develops red colour with carmine in high concentration of sulfuric acid. The transmittancy of this solution is compared with the standard colour by photoelectric colorimeter. This red colour of the solution obeys the Lambert-Beer's law in the range of boron content $0 \sim 8 \gamma \mathrm{\gamma} / \mathrm{cc}$. $\mathrm{NO}_{3}^{-}, \mathrm{F}^{-}$and $\mathrm{Cu}^{2+}$ interfere the colour development, while $\mathrm{NO}_{2}^{-}, \mathrm{Cl}^{-}$, $\mathrm{PO}_{4}^{3-}, \mathrm{NH}_{4}^{+}, \mathrm{Ca}^{2+}, \mathrm{Mg}^{2+}, \mathrm{Fe}^{3+}$ and $\mathrm{Na}^{+}$do not interfere. Some experimental details are discussed.

(Received December. 12, 1954) 


\section{1. 緒言}

䃺素の微量定量法にはこれまで分光分析” や容量分 析2”が多く用いられている. 容量分析法には Chapin 法 およびそれらの改良法"3) があるが，何れも炭酸ガスの影 響を無視することが出来ない、これらの方法は嘲素の多 い場合の定量に適するが地下水，植物，岩石，金属等に 含まれる微量の硼素の定量には適当でないと思われる. そこで微量嘲素をメチルアルコールで蒸溜して比色する 方法を試みた。硼素の比色試薬にはキナリザリン ${ }^{4) 5)}$ ，ク ルクミン(6), $1 \cdot 1^{\prime}$-ジアントリマイド8), クロモトロー

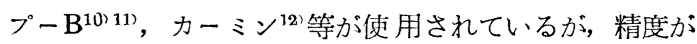
良く操作が簡単で最高発色までに長い、特間を要せず著じ るしく高い濃度の硫酸を使用しないものとしてカーミン を撰んだ.

カーミン酸は金属水酸化物とレーキを作るがカーミン 酸のアルミニウムレーキがカーミンである.

\section{2. 装 置}

光電管比色計 $\mathrm{A} \cdot \mathrm{K} \cdot \mathrm{A}$ 光電管比色計を使用した. フィルターは No. 11, $6100 \AA ̊$, キュベットは石英製の $10 \times 20 \times 27 \mathrm{~mm}$ の大きさのものを使用した.

蒸溜装置 Chapin 法の蒸溜装置を变形した第 1 図に 示すょ5な石英製の蒸溜装置を使用した. ガラス製のも のでは䐓素の大る恐れがある. 第1図で A, B は容量 100 cc の丸底フラスュ，Cは容量 $150 \mathrm{cc}$ の三角フラスコで ある. フラスコ Bは同じものを 2 コ準備した. 逆流は D, Eによって圧力の平衡を保たせるからおこらなかった。 $\mathrm{F}$ は冷却器である.フラスコ $\mathrm{A}, \mathrm{B}$ は燐酸トレクレジル 浴で凡そ $100^{\circ} \mathrm{C}$ に加熱した。

メチルアルコール回収装置 石英製の簡単な蒸溜装置 である.(第 2 図)

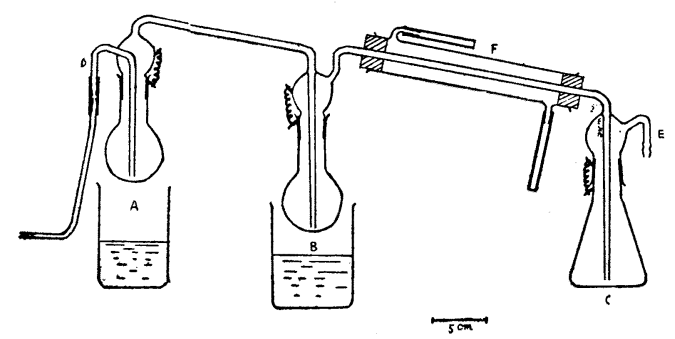

第 1 润素蒸留置

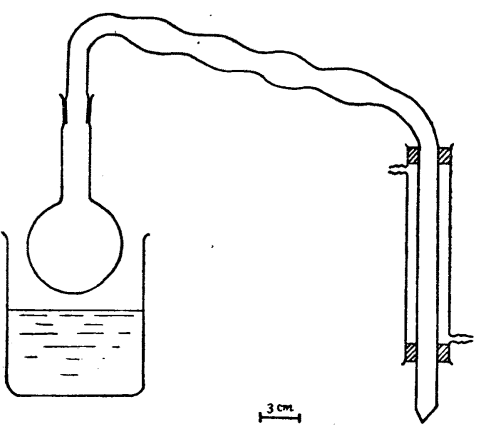

第2図 メチルアルコール回収装置

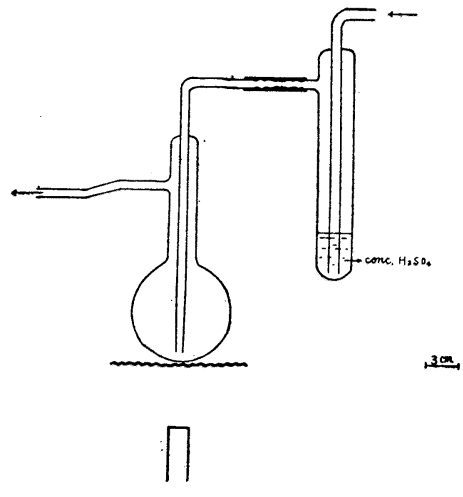

第 3 図 硫酸中碍素除去装置

発色管 共栓付き容量 $30 \mathrm{cc}$ のもの.

遠心分離器 2500 万至 $3000 \mathrm{R} / \mathrm{min}$ のもの.

\section{3. 試薬}

カーミン溶液 : $0.05 \%$ (重量), 濃硫酸 (96\%) 溶液, カーミンはメルク製のものを使用した．顕微鏡検査の際 組織染色に供するような粗製のものは使用できない。 の溶液は密栓, 保存中変色して Lambert-Beer の法則 に従 5範用が縮少されるから使用の都度新らしいものを 調製する. 冷蔵庫内に保存すれば变色は遅い.

苛性ソーダ : 粒状, 硼素を含まぬものを撰択する.

濃塩酸 : 純粋なもの.

$15 \%$ 塩酸: 純粋な濃盐酸を蒸溜水で稀釈し15\%にする. 濃硫酸 : $96 \%$ ，硼酸を含まぬすのを使用する.

著者の使用した二，三の高級硫酸は何れ\& $700 \gamma / l$ 程度の硼素を含んでいた。このような硫酸は第 3 図の如 き装置で無水硫酸の蒸気が烈しく出ない程度に 10 時間 位通気加熱して硼素を除いたものを使用する.この操作 によって硼素は $30 \gamma / l$ 程度にまで除去出来る.この程 度の硫酸は比色精度を甚しく害しない。

カーミン溶液が密栓, 保存中变色するのは濃硫酸中に 硼素を含さためと思われる，また濃硫酸中に硼素を含む と精度は悪くなるから充分除去する必要がある.

メチルアルコール: $99 \%$ (容量) 以上,アセトンを含 まぬものを使用する.

塩化カルシウム: 粒状, 無水, 硼素を含まぬものを使 用する.市販の特級塩化カルシウム (結晶) には $10 \mathrm{~g}$ 中 に 0.7 乃至 $0.8 \gamma . \mathrm{B}$ を含むものがあるから次のよ $5 に$ して除去する. 塩化カルシウムを塩酸酸性にしたメチル アルコールに溶解し重湯煎上で加熱して硼素を駆出し, 最後に強熱して無水塩化カルシウムとする.

硼素標淮浴液 : 嘲砂 $\mathrm{Na}_{2} \mathrm{~B}_{4} \mathrm{O}_{7} \cdot 10 \mathrm{H}_{2} \mathrm{O}$ (メルク製の純 精なものを使用した.）の $0.8813 \mathrm{~g}$ を溶解して $1 l$ にす れば $100 \gamma \cdot \mathrm{B} / \mathrm{cc}$ の標準溶液か得られる.これを更に稀 粕して 1 万至 $5 \gamma \cdot \mathrm{B} / \mathrm{cc}$ の標淮溶液を作る.

リトマス試験紙 : 赤色リトマス試験紙を準備する.

\section{4. 操 作}

検量線 $0,1,2,3,4 \gamma \cdot \mathrm{B} / \mathrm{cc}$ の標準溶液を作り(少く とも三ョ以上の標準溶液を作る) ピペットでこれを $2 \mathrm{cc}$ 
づつ発色管に取り濃塩酸の 2 滴を加えて振り冷却しつつ ピペットで濃硫酸 $10 \mathrm{cc}$ を加える. 振と5し充分冷却し てからピペットでカーミン溶液の $10 \mathrm{cc}$ を加光良く混和 して凡そ1時間室温に（冬季の気温の降下している時は $20^{\circ} \mathrm{C}$ 万至 $30^{\circ} \mathrm{C}$ に保温する) 密栓, 放置後 $\mathrm{A} \cdot \mathrm{K} \cdot \mathrm{A}$ 光 雪管比色計で吸光度を测定する. 硼素濃度と吸光度の検 量曲線を作る．操作は試料と同一条件で行なわなければ いけないので榆量曲線は毎回作る必要がある。

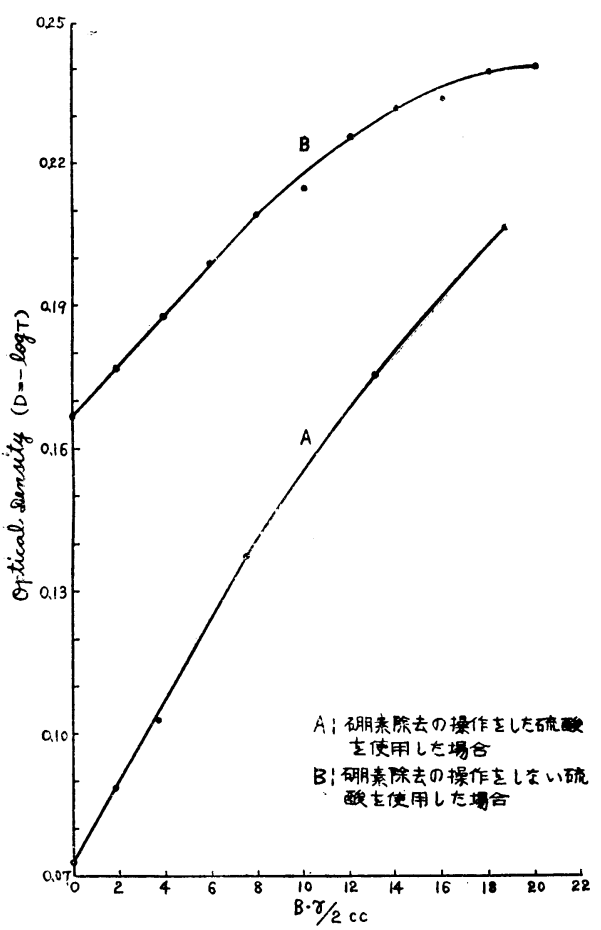

第 4 図 検 量 曲線

地下水試料の処理 地下水の $250 \mathrm{cc}$ 万至 $1000 \mathrm{cc}$ を正 確にはかりとり，石英製蒸発皿に入れ，これに粒状苛性 ソーダの 1 乃至 2 粒を加えてアルカリ性とし重湯煎上で 注意深く蒸発乾淍する. $15 \%$ 塩酸の $1.5 \mathrm{cc}$ を加えて残 涾を溶解し出来るだけ少量の蒸溜水でフラスコ Bに洗い 移す。再びこれに粒状葫性ソーダ 1 万至 2 粒を加えてア ルカリ性とし重湯煎上で蒸発乾涸する．この際確実にア ルカリ性となったか否かはリトマス試験紙で調べる.こ れに $15 \%$ 塩酸 $1.5 \mathrm{cc}$ を加えて確実に弱塩酸酸性となっ たか否かをリトマス試験紙で崕へ蒸溜装置に取りつける. フラスコ $\mathrm{A}$ にメチルアルコールの $50 \mathrm{cc}$ を大れ燐酸卜リ クレジル浴で加熱し, 冷水で泠却してあるフラスュ Bに

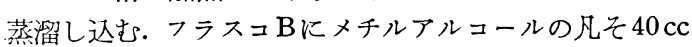

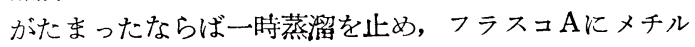
アルコール $50 \mathrm{cc}$ を補充し, フラスコ Bに無水塩化カル シウムの $10 \mathrm{~g}$ を入れる. 再び燐酸トリクレジル浴でフ

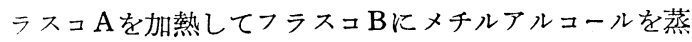
溜し入れつつフラスコ $\mathrm{B}$ 燐酸トリクレジル浴で凡そ $100^{\circ} \mathrm{C}$ に加熱し蒸溜する. この時試料中の硼素は磞酸メ チルとしてフラスュCに入る. フラスュCはあらかじめ 蒸溜水の $25 \mathrm{cc}$ (Dの先端が水につかる程度) を入れ粒
状苛性ソーダの凡そ 2 万至 3 粒でアルカリ性としておく. 蒸溜が終ったならばフラスュ $\mathrm{C}$ の溜出物(アルカリ性に なっているはずである) を第 2 区网のフラスコに入れて前 と同樣に加熱 (凡そ $95^{\circ} \mathrm{C}$ ) し，メチルアルコールを追出

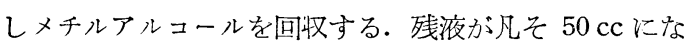
ったならばこれを石英製蒸発皿に移し, 重湯煎上で蒸発 乾涸する. 残查は $15 \%$ 塩酸 $1.5 \mathrm{c}$ で溶かし, 蒸溜水で 正確に $5 \mathrm{cc}$ にする. 不溶解物があればこれを遠心分離管 に移し, 遠心分離器によって 2500 乃至 $3000 \mathrm{R} / \mathrm{min}$ て 凡そ $10 \mathrm{~min}$ 遠心分離する.ピペットで上澄液の $2 \mathrm{cc}$ を 発色管にとり检量曲線を作ったと同様にして発色させ吸 光度を測定し，検量曲線から嗍素含有量を算出する.

白試験 塩化カルシウムが䃉素を含む恐れがあるとき は白試験をして試料の吸光度を差し引いて磞素含穹量を 算出する.

5. 検 尌

測定範囲 第 4 図は硼素濃度と吸光度との関係を表わ す曲線である.この曲線から 0 乃至 $8 \gamma \mathrm{B} / \mathrm{cc}$ の間て Lambert-Beer の法則に従 うことがわかる. 従って硼素 含有量の少いものは濃縮し, 多いものは適度に稀釈して 測定に供する，测定範囲は小であるので更に試薬，フィ ルター等の检討を加える必要がある。

好害イオン 妨害イオンについては $\mathrm{NO}_{3}^{-}, \mathrm{NO}_{2}^{-}, \mathrm{F}^{-}$, $\mathrm{Cl}^{-}, \mathrm{PO}_{4}^{3-}, \mathrm{NH}_{4}{ }^{+}, \mathrm{Ca}^{2+}, \mathrm{Mg}^{2+}, \mathrm{Fe}^{3+}, \mathrm{Cu}^{2+}, \mathrm{Na}^{+}$を調べた. $\mathrm{NO}_{3}$ - $0.1 \mathrm{mg} / 2 \mathrm{cc}, \mathrm{F}^{-}$は $10 \gamma / 2 \mathrm{cc}$ 以上で発色を減少 し, $\mathrm{Cu}^{2+}$ は $50 \gamma / 2 \mathrm{cc}$ 以上で発色を堌加する. 他のイオ ンについては妨害を認めなかった. $\mathrm{NO}_{3}{ }^{-}$の $12.5 \mathrm{mg} . \mathrm{F}^{-}$ の $2.5 \mathrm{mg}$ は前述の蒸溜操作によって完全に除去される ことを確めた。

蒸溜水 蒸溜水は銅製蒸溜器で作ったものを使用する. 蒸溜水の磞素含有量はガラス製蒸溜器に上る蒸溜水が 3.5 万至 $8.6 \gamma . \mathrm{B} / l$. 銅製蒸溜器による蒸溜水が $0.8 \gamma \cdot \mathrm{B} / l$ 程度である. 従って銅製蒸溜器によるものを使用すれば 蒸溜水による硼素の混入は無視出来る.

精度 同じ試料 A,B について同じ条件で操作して吸 光度を測定したのに次の結果を得た.この結果によって 再現性は充分良好であると思われる。

第 1 表 同一試料同一条件で吸光度を測定した結果

\begin{tabular}{lcccc}
\hline 試 & 料 & $\begin{array}{c}\mathrm{A} \text { の 吸 } \\
\text { 光度 }\end{array}$ & $\begin{array}{l}\mathrm{B} \text { の 吸 } \\
\text { 光 度 }\end{array}$ & 差 異 \\
\hline 標準溶液 $1.76 \gamma . \mathrm{B} / \mathrm{cc}$ & 0.182 & 0.181 & 0.001 \\
同 上 $2.13 "$ " & 0.176 & 0.176 & 0.000 \\
同 上 $3,52 "$ & 0.202 & 0.201 & 0.001 \\
雪 水 $250 \mathrm{cc}$ 濃 縮 & 0.167 & 0.167 & 0.000 \\
\hline
\end{tabular}

蒸溜水の $125 \mathrm{cc} 4$ בに夫及標準溶液 $0,0.88,1.76$, $2.64,3.52 \gamma . \mathrm{B} / \mathrm{cc}$ の $5 \mathrm{cc}$ を加えて前記地下水試料処理 の操作によって処理をして測定した吸光度と前記検量曲 線を作る操作によってこの標準溶液を発色させて测定し た吸光度を比較してみた. その結果は次の通りである. すなわち前記試料处理によって䂽素は充分溜出されかつ 散逸しない.また標準溶液の吸光度によって検量曲線を 
畫くと第 5 図のよ5になる。この図から理論值と実験值 は良く一致するといえる.しかし硼素は塩化カルシウム による脱水か伓充分であるとき，或い憿しく蒸溜した 時充分に駆出されないことがあるから注意しなければな らない.

比色精度は数 $\gamma . \mathrm{B} / 2 \mathrm{cc}$ で測定するとき最も良好であ り誤差は数\%以下である。また前述したよ5に精度は濃

第 2 表 蒸溜によって磞素が充分溜出し散 逸しないことを示す笑験結果

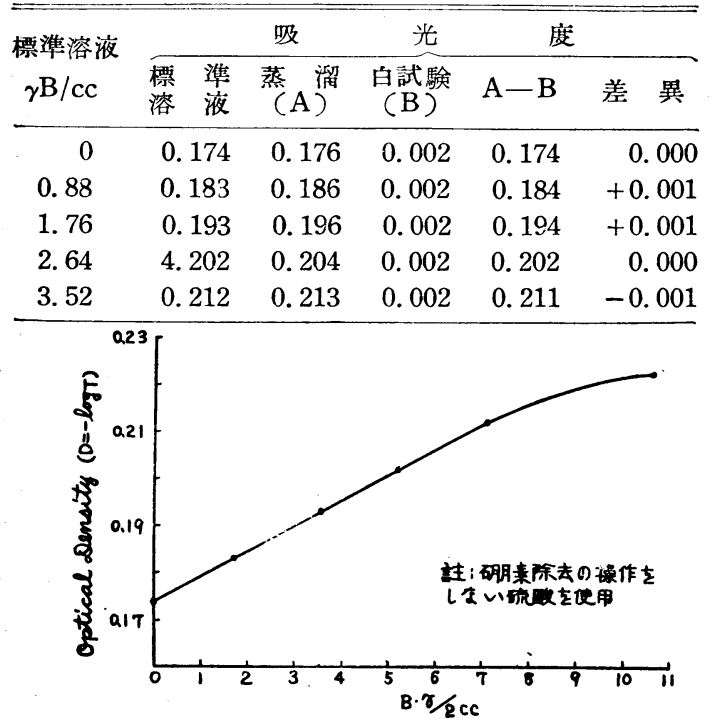

第 5 図 吸光度碍素含量関係図

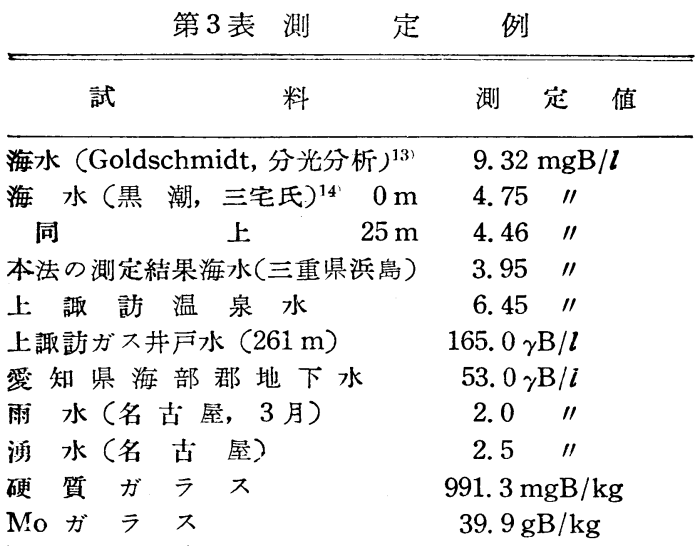

硫酸中に硼素を含むと低下するから硼素を含まないすの を使用しなければならない、第 4 図で (A) は磞素を除 去した硫酸，(B) は硼素を除去しない硫酸を夫ふ使用し た時の検量曲線である.

碍素濃度による発色差は極めて鋭敏で有り, $0.2 \gamma . \mathrm{B} / 2 \mathrm{cc}$ の相違を判別できる.

6. 測 定

二，三の試料について定量した結果は第三表のよ5で ある. 海水の碈素含有量に就ては色々の測定值が報告さ れている. Goldschmidt の分光分析結果は異常に大きな 值であるが他の值は概ねよく一致している. 多少の差䀧 が見られるのは海水塩分の濃度差によるものであろ 5 .

謝辞 本研究に対して御指導をして戴きました小穴進: 也博士および田中元治氏に深く感謝致します。

（昭和 29 年 5 月分析化学会分析化学討論会にて講演）

$$
\text { 文献 }
$$

1) 太田: 分析化学, 2, 205 (1953).

2) F. J. Foote : Ind. Eng. Chem. Anal. Ed., 4, 39 (1932).

3) L. V. Wilcox : Ind. Eng. Chem. Anal. Ed., 2, 358 (1930).

4) K. C. Berger, E. Truog: Ind. Eng. Chem., Anal. Ed., 11, 540 (1939).

5) J. R. Martin, J. R. Hayes : Anal. Chem., 24, 182 (1952).

6) J.A. Naftel : Ind. Eng. Chem., Anal. Ed., 11, 407 (1939).

7) L. Silverman, K. Trego : Anal. Chem., 25, 1264 (1953).

8) G. H. Ellis, E. G. Zook, O. Bandisch : Anal. Chem., 21, 1345 (1949).

9) D. A. Brewster : Anal. Chem., 23, 1809 (1951).

10) C. M. Austin, J.S. McMargue : J. Assoc. offic. Agr. Chem., 31, 427 (1948).

11) W. B. Healy : Anal. Chem., 23, 1716 (1951).

12) J. T. Hatcher, L. V. Wilcox : Anal. Chem., 22, 567 (1950).

13) V.M. Goldschmidt, C. Peters : Nachr. Ges. Wiss. Göttingen, Math-physik. Klasse, (1932). $402,528$.

14) Y. Miyake : Bull. C.S.J., 14, 469 (1939). 